\title{
Technology Acceptance in Augmented Reality
}

\author{
Dwi Yuniarto ${ }^{1}$, M. Agreindra Helmiawan ${ }^{2}$, Esa Firmansyah ${ }^{3}$ \\ ${ }_{1,3}^{1,3}$ sia E University \\ ${ }^{2}$ STMIK Sumedang \\ 1'c70109170014@aeu.edu.my, 2agreindra@stmik-sumedang.ac.id, ${ }^{3}$ c70109170013@aeu.edu.my
}

\begin{abstract}
Augmented Reality is now used in many fields, including in terms of helping the learning process. The purpose of this research is to know the effect of interrelated based on Technology Acceptance model, namely Perceived Usefulness, Perceived Easy to Use, Behavioral Intention Use, and Actual System Use on the use of Augmented Reality based card game. This research resulted that hypothesis in this research accepted after going through data analysis process from questionnaire result. A huge interest in the use of Augmented Reality-based games as actual technology as a factor in whether or not the game is accepted. Users, viewed in terms of ease of use and the benefits posed by the game is also very influential on the acceptance of games based on Augmented Reality.
\end{abstract}

Keywords- AR, TAM, Questionnaire, Data Analysis.

\section{INTRODUCTION}

Various ways in delivering current teaching are very developed, one of them is by using Augmented Reality (AR) technology. The technology can be integrated with various things well in everyday life in the future. AR can convey information through animation. Through this animation one of the products in teaching to children is used. Researchers in this case take the example, namely the Muslim card game. The Muslim card game provides religious teaching to children. In the use of the game is very simple, by shooting the camera to the card with a camera or application on the smartphone, it will show a hologram featuring activities related to guidance for Muslims. Augmented Reality can be used on mobile phones, related to it, need to be analyzed further. Users spend a lot of time and can cause users to become less physically active and cause vision problems [1]. AR (Augmented Reality), a technology that changes the real environment in a virtual form. Smartphone or tablet users as a medium in the Augmented Reality process, has provided a great opportunity for people to get used to the various fields [1], [2], for example for museums, Augmented Reality attraction [1]-[3] allows media content consisting of graphics, animations, and videos that provide a way for the purposes of that field [1]-[3].

Technology Acceptance Model (TAM) has been applied to a number of research disciplines, recently also AR, but studies focusing on the context of tourism are still scarce. Because this field is expected to become increasingly important rapidly due to technological advances and research in function, acceptability and usability, it is important to identify what basic requirements are required for $\mathrm{AR}$ to be accepted by users. In addition, the provision of conceptual models provides researchers with a starting point where they can base their future research [2]. As stated by Nilwafa Praduta as the developer of the Muslim card game, the initial idea of a Muslim card game is the fulfillment of the need to assist in teaching children about Islam. Like most parents in meeting those needs, think and hope there is a solution how children can catch quickly and understand without any compulsion in understanding the teachings of Islam. Based on technological developments and the presence of Muslim card games as a teaching medium for children, researchers need to evaluate the extent of acceptance of Muslim card games based on Augmented Reality technology.

To measure the extent of acceptance of Muslim card game based on Augmented Reality (AR) technology, researchers use the Technology Acceptance Model (TAM). Technology Acceptance Model (TAM) is a process of technology integration developed by Davis (1989) that perceives the user in determining behavior in utilizing technology [4], [5]. In research conducted by Davis, the ability to predict peoples' computer acceptance from a measure of their intentions, and the ability to explain their intentions in terms of their attitudes, subjective norms, perceived usefulness, perceived ease of use, and related variables [6]. Davis and Venkatesh present research develops and tests a theoretical extension of the Technology Acceptance Model (TAM) that explains perceived usefulness and usage intentions in terms of social influence and cognitive instrumental processes [7], [8]. The extended model, referred to as TAM2, was tested using longitudinal data collected regarding four different systems at four organizations, two involving voluntary usage and two involving mandatory usage [9], [10]. In Venkatesh, Morris, and Davis paper, they (1) review user acceptance literature and discuss eight prominent models, (2) empirically compare the eight models and their extensions, (3) formulate a unified model that integrates elements across the eight models, and (4) empirically validate the unified model. The eight models reviewed are the theory of reasoned action, the technology acceptance model, the motivational model, the theory of planned behavior, a model combining the technology acceptance model and the theory of planned behavior, the model of PC utilization, the innovation diffusion theory, and the social cognitive theory [9]. 
To facilitate the necessary measurements of researchers based on the background of the above problem, then the problem formulation is as follows,

H1. Does ease of use perception affect the perception of usefulness (persceived usefulness) of AR-based Muslim card game?,

H2. Does perceived usefulness affect the behavioral intention of use of AR-based Muslim card games?

H3. Does ease of use perception affect behavior interest in use (behavioral intention of use) of AR-based Muslim card game?,

H4. Does the behavioral intention of use affect actual users using the AR-based Muslim card game?

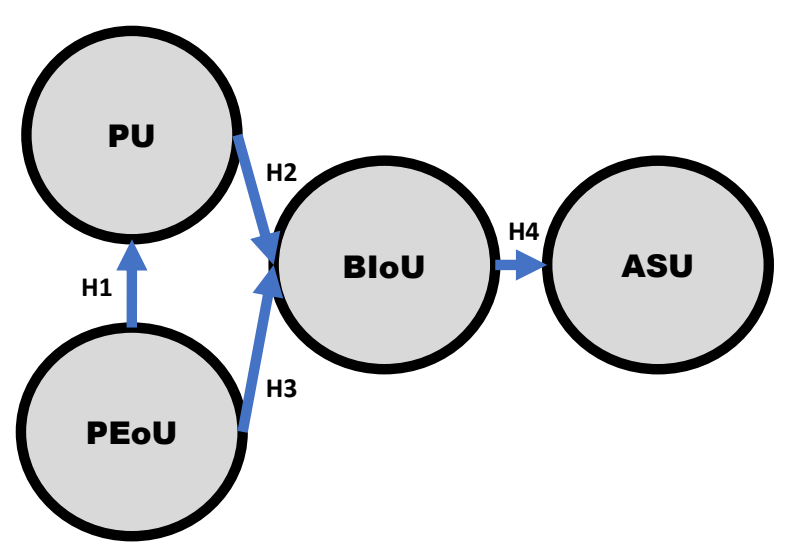

Figure 1. Research Model

This study consists of four stages, beginning with the introduction followed by explanation of research methods used, the next is about the discussion and the results, and the last in the study is the conclusion.

\section{RESEARCH METHODS}

In the discussion on this research method, researchers conducted research with several stages that have been detailed [11]. Stages in this research method consists of 3 (three) stages, namely T1, T2, and T3. In the first stage (T1) the researcher conducted the Literature Review activity first about the models used in this research, the models obtained then made the research program along with the stage of initiated models and theories. The second stage (T2) is the stage of operationalization, at this stage the researcher undertakes the activities of research instrument which is then disseminated. After the questionnaires distributed to several respondents, the researchers processed the questionnaire.

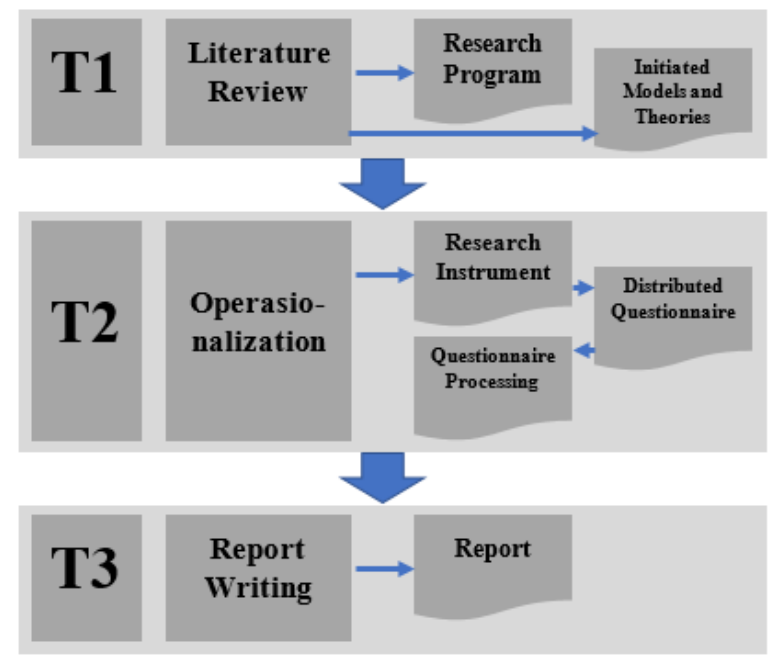

Figure 2. Research Procedure

In the final stages (T3), researchers do report writing activities as material for the final report of this research.

\section{RESULTS AND DISCUSSION}

A. Descriptive Analysis Result

This section describes the results of the questionnaire distribution. The sample in this study amounted to 140 respondents, consisting of 22 teachers, 30 parents and 88 students.

\begin{tabular}{ccc}
\multicolumn{2}{c}{ Table 1. Respondent Profile } \\
\hline Category & Item & $\%$ \\
\hline Gender & Male & $80 \%$ \\
\cline { 2 - 3 } & Female & $20 \%$ \\
\hline Status & Teacher & $16 \%$ \\
\cline { 2 - 3 } & Student Parents & $21 \%$ \\
\cline { 2 - 3 } & Students & $63 \%$ \\
\hline
\end{tabular}

B. Calculation Result Analysis Model

Discriminant validity test results based on cross loading and AVE are as stated in the following table.

Table 2. Discriminant Validity Result

\begin{tabular}{ccccc}
\hline & ASU & BIU & PEOU & PU \\
\hline ASU1 & 1.0475 & 0.6736 & 0.5083 & 0.5237 \\
\hline ASU2 & 0.8274 & 0.3603 & 0.0243 & 0.3448 \\
\hline BIU1 & \multicolumn{4}{c}{ Rejected } \\
\hline BIU2 & 0.5629 & 0.9317 & 0.6290 & 0.5572 \\
\hline BIU3 & 0.4592 & 0.8404 & 0.3533 & 0.4218 \\
\hline PEOU1 & 0.3026 & 0.5501 & 1.1318 & 0.5917 \\
\hline PEOU2 & \multicolumn{4}{c}{ Rejected } \\
\hline PEOU3 & 0.3915 & 0.5877 & 0.8388 & 0.4952 \\
\hline PEOU4 & \multicolumn{4}{c}{ Rejected } \\
\hline PU2 & 0.4746 & 0.4154 & 0.4163 & 0.8251 \\
\hline PU3 & 0.2034 & 0.4084 & 0.4930 & 0.9330 \\
\hline
\end{tabular}

Technology acceptance in Augmented Reality 


\begin{tabular}{ccccc} 
& ASU & BIU & PEOU & PU \\
\hline PU4 & 0.5298 & 0.5167 & 0.4577 & 0.7053 \\
\hline PU1 & 0.2286 & 0.3756 & 0.3111 & 0.6103 \\
\hline
\end{tabular}

From the results above, there is a construct correlation with the measurement items smaller than other constructs, namely: BIU1, PEOU2, and PEOU4. AVE or Average Variance Extracted is obtained as follows:

Table 3. Path Coefficients PLS Algorithms Results

\begin{tabular}{ccccc}
\hline \multicolumn{7}{c}{ AVE } & $\begin{array}{c}\text { Composite } \\
\text { Reliability }\end{array}$ & R Square \\
\hline ASU & 0.8909 & 0.9416 & 0.3380 \\
\hline BIU & 0.7872 & 0.8806 & 0.4156 \\
\hline PEOU & 0.9923 & 0.9960 & 0.0000 \\
\hline PU & 0.6053 & 0.8568 & 0.3033 \\
\hline \multicolumn{5}{c}{} \\
\hline \multicolumn{7}{c}{ Cronbach } & $\begin{array}{c}\text { Cronbach } \\
\text { s Alpha }\end{array}$ & $\begin{array}{c}\text { Commu } \\
\text {-nality }\end{array}$ & $\begin{array}{c}\text { Redun } \\
\text {-dancy }\end{array}$ \\
\hline ASU & 0.5086 & 0.5086 & 0.9520 & 0.0234 \\
\hline BIU & 0.5707 & 0.5707 & 0.9643 & 0.0223 \\
\hline PEO & 0.5907 & 0.5907 & 0.9535 & 0.0000 \\
U & \multicolumn{5}{c}{0} \\
\hline PU & 0.5945 & 0.5945 & 0.9152 & 0.0161 \\
\hline
\end{tabular}

Results from AVE, Composite Reliability, RSquare, Croncbachs Alpha show good results. So that each collision meets the criteria[12]. To know the relationship between variables and hypothesis testing through Bootstrapping as follows:

Table 4. Path Coefficients from Bootstrapping Results

\begin{tabular}{|c|c|c|c|c|c|}
\hline & $\begin{array}{c}\text { Org } \\
\text { Sample } \\
(\text { O) }\end{array}$ & $\begin{array}{l}\text { Sample } \\
\text { Mean } \\
\text { (M) }\end{array}$ & $\begin{array}{c}\text { Stand } \\
\text { Deviation } \\
\text { (STDEV) }\end{array}$ & $\begin{array}{c}\text { Stand } \\
\text { Error } \\
\text { (STER } \\
\text { R) }\end{array}$ & $\begin{array}{c}\mathbf{T} \\
\text { Statistics } \\
(\mid \mathrm{O} / \\
\text { STERR } \mid)\end{array}$ \\
\hline$\stackrel{\text { BIU- }}{>}$ & 0.5814 & 0.5841 & 0.0822 & 0.0822 & 7.0722 \\
\hline $\begin{array}{c}\text { PEO } \\
\mathbf{U}- \\
>\mathbf{B I} \\
\mathbf{U}\end{array}$ & 0.3822 & 0.3850 & 0.0950 & 0.0950 & 4.0213 \\
\hline $\begin{array}{c}\text { PEO } \\
\mathbf{U}- \\
>\text { PU }\end{array}$ & 0.5507 & 0.5545 & 0.0689 & 0.0689 & 7.9945 \\
\hline $\begin{array}{l}\text { PU - } \\
\text { BIU }\end{array}$ & 0.3497 & 0.3536 & 0.0901 & 0.0901 & 3.8797 \\
\hline
\end{tabular}

So from the process of Bootstrapping produce $\mathrm{H} 1$, $\mathrm{H} 2, \mathrm{H} 3$, and $\mathrm{H} 4$ as follows.
Table 5. Hypothesis Testing Results

\begin{tabular}{cccc}
\hline & $\begin{array}{c}\text { Origin } \\
\text { al } \\
\text { Sample } \\
(\mathbf{O})\end{array}$ & $\begin{array}{c}\text { T } \\
\text { Statistics } \\
(\mid \mathbf{O} /\end{array}$ & Results \\
$\mathbf{S T E R R} \mid)$ & \\
\hline BIU -> ASU & 0.5814 & 7.0722 & $\begin{array}{c}\text { H1 }= \\
\text { ACCEPTED }\end{array}$ \\
\hline $\begin{array}{c}\text { PEOU -> } \\
\text { BIU }\end{array}$ & 0.3822 & 4.0213 & $\begin{array}{c}\text { H } 2= \\
\text { ACCEPTED }\end{array}$ \\
\hline $\begin{array}{c}\text { PEOU -> } \\
\text { PU }\end{array}$ & 0.5507 & 7.9945 & H3 $=$ \\
\hline $\begin{array}{c}\text { PU -> BIU } \\
\text { ACCEPTED }\end{array}$ \\
\hline
\end{tabular}

From the table, behavioral intention of use generates the actual user use of AR-based Muslim card games, and ease of use perceptions affect the behavioral intention of use of card games AR-based Muslims, ease of use perceptions affect the perception of usefulness of the AR-based Muslim card game, and perceived usefulness affect the behavioral intention of use of AR-based Muslim card games.

\section{CONCLUSION}

A huge interest in the use of Augmented Realitybased games as actual technology as a factor in whether or not the game is accepted. Users, viewed in terms of ease of use and the benefits posed by the game is also very influential on the acceptance of games based on Augmented Reality. So it is certain that the users in this case Teachers, Parents, and Students / I receive the Augmented Reality-based game. This research can serve as a reference for the application of Augmented Reality in various fields, especially learning.

\section{REFERENCES}

P. Jankaweekool and T. Uiphanit, "User Acceptance of Augmented Reality Technology : Mobile Application for Coin Treasury Museum," in Proceedings of ISER 72nd International Conference, 2017, no. August, pp. 8-13.

M. C. Leue, D. Dieck, and T. Jung, “A Theoretical Model of Augmented Reality Acceptance," $e$ Review Tour. Res., 2014.

[4] F. D. Davis, "Perceived Usefulness, Perceived Ease of Use, and User Acceptance of Information Technology," MIS Q., vol. 13, no. 3, p. 319, 1989.

[5] W. S. Davis and D. C. Yen, The information system consultant's handbook: systems analysis and design. CRC Press, 1999.

[6] F. D. Davis, R. P. Bagozzi, and P. R. Warshaw, "User Acceptance of Computer Technology: A Comparison of Two Theoretical Models," Manage. Sci., vol. 35, no. 8, pp. 982-1003, 1989.

[7] D. Yuniarto, "Analisis Penerimaan Penggunaan Aplikasi Laporan BKD dan Evaluasi Pelaksanaan Tridharma PT Online menggunakan TAM,” 2018

[8] D. Yuniarto, "Analisis Penerimaan Penggunaan 
Aplikasi Grab di Kabupaten Sumedang," Infoman's, pp. 78-85, 2017.

[9] V. Venkatesh and F. D. Davis, "A Theoretical

Extension of the Technology Acceptance Model:

Four Longitudinal Field Studies," Manage. Sci., vol. 46, no. 2, pp. 186-204, Feb. 2000.

[10] V. Venkatesh, M. G. Morris, G. B. Davis, and F. D. Davis, "User Acceptance of Information Technology: Toward a Unified View," MIS Q., vol. 27, no. 3, p. 425, 2003.

[11] J. W. Creswell, Research design : qualitative, quantitative, and mixed methods approaches. SAGE Publications, 2014.

[12] J. Henseler, G. Hubona, and P. A. Ray, "Using PLS path modeling in new technology research: updated guidelines," Ind. Manag. Data Syst., vol. 116, no. 1, pp. 2-20, Feb. 2016. 